\title{
Medical Students' Perception of the Educational Environment at Al-Nahda College by using DREEM inventory
}

Hamdan Z. Hamdan ( $\square$ hamdanology@hotmail.com )

Al-Neelain University https://orcid.org/0000-0001-9269-8239

Marwa Yassin Ibrahim

Al-Nahda College

Rania Hessian Mohamed

Al-Nahda College

Liza Hassan Ali

Al-Nahda College

Yasir A. Mohamedelhassan

Al-Nahda College

Nasreldin Marhoum Ahmed

King Saud University

Research article

Keywords: DREEM, Al-Nahda College, Sudan, educational environment

Posted Date: February 13th, 2020

DOI: https://doi.org/10.21203/rs.2.18687/v2

License: (1) This work is licensed under a Creative Commons Attribution 4.0 International License.

Read Full License 


\section{Abstract}

Background: Educational environment encompasses everything that is found and occurs inside medical school. It affects students' ability to achieve their academic goals, feelings of academic satisfaction, and well-being. Assessment of the educational environment is of paramount importance for stakeholders, administrators and educators in the academic field. The aim of this study was to measure student perceptions of the educational environment in a medical college in Sudan.Methods: This was an institutional-based cross-sectional study conducted in Al-Nahda College, Khartoum, Sudan, between January and February 2018 with a sample of 634 medical students (56.9\% male; pre-clinical (83.9\%) and clinical (16.1\%) students). The Dundee Ready Education Environment Measure (DREEM) questionnaire was used as a survey tool. Overall DREEM score was compared with students' academic levels by using one-way ANOVA after Tukey's test. Students' gender, academic levels and nationality were used as independent variables determining the overall DREEM score by using multivariate analysis. Student's ttest was used to compare the overall scores among all students based on gender and academic levels (clinical and pre-clinical).Results: The overall mean (SD) DREEM score in this study was 130 (34.2), which indicates a more positive educational environment than negative. Student perception of teachers, academic self-perception, perception of atmosphere and social self-perception was positive. However, perception of learning was negative. Female students had a significantly higher mean (SD) overall DREEM score than males [136 (31.5) vs. 129 (35.5); P=0.008]. There was no significant difference in overall DREEM score between pre-clinical and clinical students [132 (33.3) vs. 132 (38.3); P= 0.946]. Females scored higher than males in the subclasses regarding students' perception of teachers, academic self-perception and social self-perception [28.8 (7.8) vs. 27.1 (8.5); $P=0.024]$; [22.2 (5.6) vs. 21.0 (7.2); $P=0.017] ;[19.8$ (4.9) vs. 18.8 (5.4); $P=0.019]$, respectively. Univariate analysis showed that student gender significantly determines the overall DREEM score [Beta \pm SE; P-value].Conclusions: The educational environment is generally perceived as positive in Al-Nahda College. Perception of learning was the only sub-scale regarded as negative. Females perceived the educational environment more positively than males.

\section{Background}

The process of evaluation is one of the cornerstones of educational management. It is best defined as a periodic process to assess overall academic work [1]. 'Educational environment' is a complex term that refers to the social, psychological, and physical locations where students learn [2, 3]. In addition to the infrastructure and university setting, it encompasses the attitude of teachers inside the class and the methods they use to deliver learning materials to students. It also includes the type of curriculum and the methods of teaching used to deliver the curriculum. Collectively, the educational environment can be defined as everything that affects the learning process whether directly or indirectly [4].

It is widely accepted that evaluation of the learning environment in a medical school is one of the major components of medical school program appraisal. It is postulated that learning environment affects the ability of students to learn [3]. Moreover, Lizzio et al. reported an association between the learning 
environment and development of students' basic skills, academic achievement and learning satisfaction [5]. Successful intervention at the curriculum level needs constructive periodic feedback from students themselves. Thus, identification of areas of concern that hinder students' academic performance is of paramount importance for faculty, curriculum planners and institute directors [6]. A sensitive and reliable assessment tool is needed to measure the learning environment in a scientific way, and it should be able to express and represent the data quantitatively.

In 1997, a Dundee University team presented an assessment tool that could measure the environment and the atmosphere for education in a medical school. It was named the 'Dundee Ready Educational Environment Measure' (DREEM). This tool was accepted worldwide as a reliable and valid assessment tool to measure the environment of medical schools. This universal consensus may be attributed to its method of development. First, it involved almost 100 medical educators from around the world using Grounded theory and a Delphi procedure. Second, it had been used with over 1000 medical students internationally. Third, it combines quantitative and qualitative methods that consider many different nationalities and cultures, and is not biased towards a specific community $[7,8]$.

There are few studies conducted in sub-Saharan Africa using the DREEM inventory to measure the educational environment [9-11]. In Sudan, there are 32 public and 42 private medical schools [12]. Only 2 out of the 32 public medical schools have reported DREEM scores for their students [13, 14]. Al-Nahda College is a private college established in Khartoum, Sudan with its first intake of students in 2013. The curriculum used in the college is a modified integrated curriculum. Since its establishment the curriculum of the college has not been reviewed and no feedback has been received from students. Therefore, the current study was conducted to describe student perceptions about the educational environment at the college and to identify areas of strength that need to be maintained, and areas of weaknesses which need improvement for the enhancement of the educational environment as a whole. The results of this study may be used as baseline data for future interventions in the curriculum.

\section{Methods}

This was an institutional-based cross-sectional study. It was conducted in Al-Nahda College between January and February 2018. The study sample comprised medical students of all academic levels (first to fifth year). Al-Nahda University College uses an integrated curriculum with both longitudinal themes and horizontal integrated block modules. On completion of five academic years, graduates obtain a Bachelor of medicine and Bachelor of surgery (MBBS). In the first three years systems courses emphasize basic sciences with some clinical background. Pure clinical teaching is applied for the final two years. The total number of students in the Medicine and Surgery Program is 874 students. We used the total coverage approach to sampling and tried to collect responses from the majority of students. The study was explained to all students by one of the investigators who had received training on data collection and communication with students over the course of one day. The investigator approached the students to participate in the study in the class after a lecture. Those who agreed to participate were asked to fill in the questionnaire without writing their names. The questionnaire was in English, which was not a 
problem as the medium of teaching at the college is also English. The investigators added some demographic data that included age, gender, academic level and nationality.

Data were collected using the Dundee Ready Measure for Educational Environment (DREEM) questionnaire, which is composed of 50 questions each scored by $0-4$ on a five-point Likert scale (strongly agree $=4$; agree $=3$; uncertain $=2$; disagree $=1$; strongly disagree $=0$ ). The scale has nine questions where scoring is reversed (numbers $4,8,9,17,25,35,39,48$ and 50) to take into account negative wording. The maximum score of the overall scale is 200 . The interpretation of the overall score is as follows: $0-50$ indicates very poor educational environment; $51-100$ indicates many problems; 101-150 more positive than negative and 151-200 suggests an excellent educational environment. The scale contains five subclasses as follows:

\section{Students' perception of learning:}

This domain contains 12 questions with a maximum score of 48 . The scores are interpreted as follows: $0-12,13-24$, and $25-36$ are interpreted as very poor, negative, and a more positive approach, respectively [15].

\section{Students' perception of teachers:}

This domain contains 11 questions with a maximum score of 44 . The scores are interpreted as follows: $0-11,12-22,23-33$, and $34-44$ are considered as abysmal, in need of some retraining, moving in the right direction, and model teachers, respectively [15].

\section{Students' academic self-perception:}

This domain contains eight questions with a maximum score of 32 . The scores are interpreted as follows: $0-8,9-16,17-24$, and $25-32$ are interpreted as a feeling of total failure, many negative aspects, feeling more on the positive side, and confident, respectively [15].

\section{Students' perception of atmosphere:}

This domain contains 12 questions with a maximum score of 48 . The scores are interpreted as follows: $0-12,13-24,25-36$, and $37-48$ were considered as a terrible environment, there are many issues that need to change, a more positive atmosphere, and a good feeling overall, respectively [15].

\section{Students' social self-perception:}

This domain contains seven questions with a maximum score of 28 . Scores can be interpreted as follows: $0-7,8-14,15-21$, and $22-28$ were considered as miserable, not a nice place, not too bad, and very good socially, respectively [15]. Further, every item can be considered as an area that needs particular attention, an area that can be improved or a strong area based on scores $\leq 2.0,2-3$ and $\geq 3.5$, respectively [15]. 


\section{Statistical analysis}

Data were entered, double-checked and analysed using Statistical Package for Social Sciences (SPSS) (version 24; SPSS Inc. Chicago, IL, USA). The data were expressed as mean (SD) or number (\%). Students' gender, nationality and academic level were used as independent variables. Linear regression analysis took place using the DREEM score as dependent variable and students' gender, academic level and nationality as independent variables. The mean (SD) of DREEM overall score and subclass score were compared between five academic levels of the students using one-way ANOVA followed by Tukey's test. The mean (SD) of DREEM overall score and subclass score were compared between males and females, and between clinical ( $4^{\text {th }}$ and $5^{\text {th }}$ level) and pre-clinical $\left(1^{\text {st }}-3^{\text {rd }}\right.$ level $)$ students by using Student's $t$-test after checking the variance. $P$-values $\leq 0.05$ were considered statistically significant.

\section{Results}

A total of 670 students were successfully approached and 36 refused to participate. The response rate was $94.6 \%$. A total of 634 medical students participated in the study representing all academic levels including pre-clinical (83.9\%) and clinical (16.1\%) students. Three hundred and sixty-one participants $(56.9 \%)$ were male. Five nationalities participated in this study, namely: Sudanese, Nigerian, South African, Syrian, and Egyptian students. Sudanese nationality was the most common (71.9\%), while Nigerian (18.1\%) was the most common nationality for foreign students and Egyptian was the least common (1.3\%) (Table 1).

The overall DREEM score in this study was 130 , which indicates a more positive educational environment than negative. Likewise, students' perceptions of teachers, academic self-perception, perception of atmosphere and social self-perception were also positive. However, student perception of learning showed a negative indicator (Table 2).

Females had a significantly higher mean (SD) overall DREEM score than male students [136 (31.5) vs. 129 (35.5); $P=0.008]$. Also, females scored higher than males in the subclasses regarding student perception of teachers, academic self-perception and social self-perception, [28.8 (7.8) vs. 27.1 (8.5); $P=0.024] ;[22.2$ (5.6) vs. 21.0 (7.2); $P=0.017$ ]; [19.8 (4.9) vs. 18.8 (5.4); $P=0.019]$, respectively. Grouped (clinical and pre-clinical) and separated academic levels did not show any significant effects in the perception of the students towards the overall DREEM score or the subclasses (Table 3 and Table 4). None of the detailed items scored less than 2 or more than 3 (Table 5). The linear regression analysis model showed that student gender significantly affects overall DREEM score [7.65 $\pm 2.91 ; P$-value= 0.009$]$ (Table 6).

\section{Discussion}

To the best of our knowledge, this is the first DREEM study reported from a private medical school in Sudan. The major finding is that the overall DREEM score of $130 / 200$ indicates a more positive than 
negative educational environment in the Al-Nahda medical program. This result is in-line with Ahmed et al., and Salih et al., who conducted studies in public national universities in Sudan, namely the University of Al-Gezira and Bahri University where scores of 122/200 and 125.2/200 were obtained, respectively [13, 14]. The positive scores in these studies, as well as our own, point to a well-established infrastructure, an integrated and student-centred curriculum, skilful teachers and a good social-environment. Each of these aspects has been key for Al-Nahda College since its establishment. The result is comparable to other international medical schools like Ziauddin University in Pakistan (117/200), King Abdul Aziz University (102/200), Taibah University (120/200) and Qassim University in Saudi Arabia (112/200) [16-19]. However, the score exceeds that of medical schools at Jazan University (96.5/200), King Saud University in Saudi Arabia (90/200), and Guilan Medical University in Iran (100/200). Scores from these institutes indicate educational environments with many problems [20-22] despite the fact that these three institutes were established in economically powerful countries with ample logistics and resources. Students perceive a negative educational environment, suggesting that economic power is not the only determinant of the educational environment and there are other factors beyond the facilities of the educational environment [20]. The DREEM inventory was used to measure the educational environment as it is widely accepted as a reliable way to compare educational environments in different medical schools around the world. DREEM considers international differences in culture, moral issues and languages. DREEM has strong psychometric properties which enable the tool to be used to evaluate medical schools for international comparison in a valid and reliable way [23].

In the current study, students perceived their teachers positively. However, student perception of learning indicates a negative perception. A positive perception of teachers is an outcome of a faculty continuous development plan implemented by the Educational Development Centre and aimed at enhancing the faculty's capacities in preparation and delivery of teaching materials, setup of blue-printing, standard settings and student assessment. Moreover, the college follows a specific and rigorous recruitment procedure that ensures selection of staff with the highest academic grades and strong academic teaching experience. This finding is in line with other universities in Sudan and outside of it $[13,24]$.

Student academic self-perception was positive in our study with a score of $21.5 / 32$. Academic selfperception is defined by Kohli and Dhaliwal as being "related to ability of the students to cope with the academic workload" [25]. Although many studies report low scores and negative perceptions in this domain, indicating a global challenge $[26,27]$, our result is similar to that reported by other studies from Sudan (21/32) and Malaysia (20.6/32) [11,14]. Well-designed and prepared timetables - with more time allocated to self-directed learning - are a leading cause for this positive perception. However, delivery of many teaching activities in a very restricted time is considered a challenge in medical education. Whether the teaching curriculum is traditional or innovative [26,27], students often feel overloaded by academic duties and this overwhelming sensation may result in frustration and sometimes depression [28]. Female students had academic self-perception that was significantly more positive than that of their male counterparts. Australian DREEM supports our findings [29]. 
Student perception of the atmosphere in our study scored 32.7/48 and showed a more positive perception than other DREEM reports from Sudan (26/48) and Saudi Arabia $(30.2 / 48)[11,16]$. Educational atmosphere refers to the teaching class and clinical setup, and teachers' behaviour during the teaching sessions and clinical rounds. It also includes curriculum design and academic regulation. Some reports indicate that a teacher-centred curriculum focused on lecturing is boring [30,31]. Here students are subjected to a less motivating environment in contrast to problem-based learning [32]. There were neither gender nor academic ranking differences in the perception of this domain.

In this study, students perceived their social life as more positive $(19.2 / 28)$ than in many institutes in Sudan (17/28), Pakistan (15.4/28) and Malaysia (16.7/28) [13, 17, 33]. These findings regarding social life in this study are not surprising and may be partially attributed to the out-of-class activities, journeys and open cultural days regularly organized by the students' deanship. These journeys and open days create a robust social environment and relationships between students and with the academic and administrative staff. Moreover, the student mentoring program is one of the important determinants of the social life which ensures a strong psychological support and feedback system [25]. Although the mentoring program is not well known, an advisory program for students was implemented in the last two years with aims very close to those of a mentoring program. Female students perceived the social life significantly more positively than male students, as was seen at the College of Medicine at Taibah University [19].

Students' perceptions of learning indicated a negative educational environment. This is a major concern for many international universities [26, 34-36]. To obtain a good learning perception, researchers recommend structured learning for clinical and theoretical teaching. Moreover, more time should be allocated for tutorial sessions, and the adoption of small teaching group techniques and other innovative approaches [37]. Although there was no item that scored below 2 in this subscale, items that scored lowest were: "I am clear about the learning objectives of the course" and "I am encouraged to participate during teaching sessions". Clarity of learning objectives is a cornerstone of adult learning principles, and participation in discussions reflects students' cognitive activity [38]. This subscale suggests need for urgent intervention that includes: explaining of the learning objectives to the students for each teaching session or at least for every module. Small group discussions should be held more frequently and with encouragement for each student to participate in the session. This domain should be considered at the time of curriculum appraisal and in all long-term planning.

In this study we observed that females perceive the overall educational environment, their teachers, their academic and social self-perception significantly more positively than male counterparts. There is no clear reason for this, however, it may be attributed to the way of thinking, learning style, concern and interest of the female gender over the male gender [39]. Possibly, gender bias favouring female teaching and assessment is the case here [40]. From another point of view, Makhdoom and his colleagues observed that high academic achievers specifically perceived their teachers far more positively than nonacademic achievers. Perhaps female students constitute a high proportion of the higher academic 
achievers. However, we did not enquire about academic achievement in this study. More than three decades ago Carol Gilligan and Susan Pollak (1988) noted:

The increasing number of women entering the medical profession prompts a rethinking of medical education. Like the canaries taken into mines to reveal the presence of unseen dangers, women medical students in their heightened sensitivity to detachment and isolation often reveal the places in medical training and practice where human connection has become dangerously thin [41].

Perhaps, this high female sensitivity has led to the differences noted in the perception of the majority of the domains.

In this study, students' ranking (clinical or pre-clinical) failed to show any significant difference in the overall DREEM score or any of the subscale domains. This may be attributed to the motivation and excitation associated with the admission to the school of medicine and a feeling of determination in the pre-clinical phase. Students in the clinical phase may be fully aware of the complexity of the clinical phase and the efforts needed for bedside teaching so they may be more realistic. However, they are still optimistic about their future as they are about to leave student life behind and become a doctor. Findings in the literature are conflicting $[13,39,42]$.

This is the first study that documents the educational environment in Al-Nahda College and it has many limitations. First, although the DREEM inventory is well structured, valid and reliable, it is long and students may have become bored when responding to the items, which may then have affected the responses obtained. Second, educational environment is a complicated issue that the predetermined options in DREEM may be too limited to address. Further study is needed to reassess the educational environment in Al-Nahda College after considering all the domains that need intervention and including the variables that are missing in this version, like students' grade point average (GPA), admission scores and secondary certificate type.

\section{Conclusions}

The overall DREEM score indicates that the educational environment was perceived as positive by the medical students. Four subscales were positive: students' perception of teachers, academic selfperception, perception of atmosphere and social self-perception. The students' perception of learning was negative. Female students perceived the educational environment significantly more positively than male students. The perception of clinical students did not differ from that perceived by pre-clinical students. Further study is needed to develop the work that has been initiated here.

\section{List Of Abbreviations}

DREEM Dundee Ready Educational Environment Measurement

GPA Grade point average 


$\begin{array}{ll}\text { IL } & \text { Illinois } \\ \text { Inc } & \text { Incorporation } \\ \text { MBBS } & \text { Bachelor of Medicine and Bachelor of surgery } \\ \text { SASP } & \text { Students' academic self-perception } \\ \text { SD } & \text { Standard deviation } \\ \text { SPA } & \text { Students' perception of atmosphere } \\ \text { SPL } & \text { Students' perception of learning } \\ \text { SPSS } & \text { Statistical package for social sciences } \\ \text { SPT } & \text { Students' perception of teachers } \\ \text { SSSP } & \text { Students' social self-perception } \\ \text { UK } & \text { United Kingdom } \\ \text { USA } & \text { United states of America } \\ \text { WFME } & \text { World Federation for Medical Education } \\ \text { Declarations }\end{array}$

\section{Ethics approvals and consent to participate}

The study received ethical clearance from AL-Neelain University Research Ethics committee. All participants provide written informed consent.

\section{Consent for publication}

Not applicable

\section{Availability of data and materials}

Authors confirm that they are ready to provide the study data and materials upon request.

\section{Competing interests}

None to declare.

\section{Funding}

Not applicable. 


\section{Authors' contributions}

$\mathrm{HZH}$ and NMA concepted and designed the study. MYI, RHM and LHA conducted the study. YMA, HZH and NMA shared in the statistical analyses. NMA, HZH and YMA share in drafting the paper. All of the authors drafted and approved this version of the paper.

\section{Acknowledgements}

The authors wish to thank all students who participate in this study and the administrative team in AlNahda College.

\section{References}

1. WIP - WikiEducator. http:// wikieducator.org/WIP.

2. Kember D, Leung DYP. Development of a questionnaire for assessing students' perceptions of the teaching and learning environment and its use in quality assurance. Learn Environ Res. 2009;12:1529. doi:10.1007/s10984-008-9050-7.

3. Genn JM. AMEE Medical Education Guide No. 23 (Part 1): Curriculum, environment, climate, quality and change in medical education-a unifying perspective. Med Teach. 2001;23:337-44. doi:10.1080/01421590120063330.

4. Bakhshialiabad H, Bakhshi M, Hassanshahi G. Students' perceptions of the academic learning environment in seven medical sciences courses based on DREEM. Adv Med Educ Pract. 2015;6:195203. doi:10.2147/AMEP.S60570.

5. Lizzio A, Wilson K, Simons R. University Students' Perceptions of the Learning Environment and Academic Outcomes: Implications for theory and practice. Stud High Educ. 2002;27:27-52. doi:10.1080/03075070120099359.

6. Genn JM. AMEE Medical Education Guide No. 23 (Part 2): Curriculum, environment, climate, quality and change in medical education - a unifying perspective. Med Teach. 2001;23:445-54. doi:10.1080/01421590120075661.

7. Soemantri D, Herrera C, Riquelme A. Measuring the educational environment in health professions studies: A systematic review. Med Teach. 2010;32:947-52. doi:10.3109/01421591003686229.

8. Roff S. The Dundee Ready Educational Environment Measure (DREEM)--a generic instrument for measuring students' perceptions of undergraduate health professions curricula. Med Teach. 2005;27:322-5. doi:10.1080/01421590500151054.

9. Mogre V, Amalba A. Psychometric properties of the dundee ready educational environment measure in a sample of Ghanaian Medical Students. Educ Health (Abingdon). 2016;29:16-24. doi:10.4103/1357-6283.178921.

10. Okoye O, Ezisi CN, Ezepue FU. Evaluation of the learning and teaching environment of the Faculty of Medical Sciences, College of Medicine, University of Nigeria, Enugu Campus. Niger J Clin Pract. 2017;20:958-63. doi:10.4103/njcp.njcp_414_16. 
11. Ogun OA, Nottidge TE, Roff S. Students' perceptions of the learning environment in two Nigerian medical schools offering different curricula. Ghana Med J. 2018;52:116-21. doi:10.4314/gmj.v52i3.2.

12. Ministry Of Higher Education. http://mohe.gov.sd/index.php/en/.

13. Salih K, Idris M, Elfaki O, Osman N, Nour S, Elsiddig H, et al. Measurement of the educational environment in MBBS teaching program, according to DREEM in College of Medicine, University of Bahri, Khartoum, Sudan. Adv Med Educ Pract. 2018;Volume 9:617-22. doi:10.2147/AMEP.S160218.

14. Ahmed Y, Taha MH, Al-Neel S, Gaffar AM. Students' perception of the learning environment and its relation to their study year and performance in Sudan. Int J Med Educ. 2018;9:145-50. doi:10.5116/ijme.5af0.1fee.

15. Vaughan B, Carter A, Macfarlane C, Morrison T. The DREEM, part 1: measurement of the educational environment in an osteopathy teaching program. BMC Med Educ. 2014;14:99. doi:10.1186/14726920-14-99.

16. Al-Hazimi A, Al-Hyiani A, Roff S. Perceptions of the educational environment of the medical school in King Abdul Aziz University, Saudi Arabia. Med Teach. 2004;26:570-3.

17. Khursheed I, Baig L. Students' perceptions of educational environment of a private medical school in Pakistan. JPMA - J Pakistan Med Assoc. 2014;64:1244-9.

18. Mojaddidi MA, Khoshhal KI, Habib F, Shalaby S, El-Bab MEF, Al-Zalabani AH. Reassessment of the undergraduate educational environment in College of Medicine, Taibah University, Almadinah Almunawwarah, Saudi Arabia. Med Teach. 2013;35 SUPPL. 1:39-46.

19. Al-Mohaimeed A. Perceptions of the educational environment of a new medical school, Saudi Arabia. Int J Health Sci (Qassim). 2013;7:150-9. doi:10.12816/0006039.

20. Hasan T, Gupta P. Assessing the learning environment at Jazan medical school of Saudi Arabia. Med Teach. 2013;35 SUPPL. 1.

21. Taheri M. Students ' perceptions of learning environment in Guilan University of Medical Sciences. J Med Educ. 2009;13:127-33.

22. Al-Ayed IH, Sheik SA. Assessment of the educational environment at the College of Medicine of King Saud University, Riyadh. EMHJ - East Mediterr Heal J. 2008;14:953-9.

23. Roff S, McAleer S, Harden RM, Al-Qahtani M, Ahmed AU, Deza H, et al. Development and validation of the Dundee Ready Education Environment Measure (DREEM). Med Teach. 1997;19:295-9.

24. Barcelo JM. Medical laboratory science and nursing students' perception of the academic learning environment at a Philippine university using the Dundee Ready Education Environment Measure. J Educ Eval Health Prof. 2016;13:33. doi:10.3352/jeehp.2016.13.33.

25. Kohli V, Dhaliwal U. Journal of Educational Evaluation for Health Professions Medical students' perception of the educational environment in a medical college in India: a cross-sectional study using the Dundee Ready Education Environment questionnaire. J Educ Eval Heal Prof. 2013;10:1-7. 
26. Thomas BS, Abraham RR, Alexander M, Ramnarayan K. Students' perceptions regarding educational environment in an Indian dental school. Med Teach. 2009;31:e185-6.

doi:10.1080/01421590802516749.

27. Edgren G, Haffling A-C, Jakobsson U, McAleer S, Danielsen N. Comparing the educational environment (as measured by DREEM) at two different stages of curriculum reform. Med Teach. 2010;32:e233-8. doi:10.3109/01421591003706282.

28. Alfaris EA, Naeem N, Irfan F, Qureshi R, Van Der Vleuten C. Student centered curricular elements are associated with a healthier educational environment and lower depressive symptoms in medical students. BMC Med Educ. 2014;14.

29. Brown T, Williams B, Lynch M. The Australian DREEM: evaluating student perceptions of academic learning environments within eight health science courses. Int J Med Educ. 2011;2:94-101. doi:10.5116/ijme.4e66.1b37.

30. Lieberman SA, Stroup-Benham CA, Peel JL, Camp MG. Medical student perception of the academic environment: a prospective comparison of traditional and problem-based curricula. Acad Med. 1997;72 10 Suppl 1:S13-5. http://www.ncbi.nlm.nih.gov/pubmed/9347725.

31. Zawawi AH, Elzubeir M. Using DREEM to compare graduating students' perceptions of learning environments at medical schools adopting contrasting educational strategies. Med Teach. 2012;34 Suppl 1:S25-31. doi:10.3109/0142159X.2012.656747.

32. Rodrigues de Oliveira Filho G, Schonhorst L. Problem-based learning implementation in an intensive course of anaesthesiology: A preliminary report on residents' cognitive performance and perceptions of the educational environment. Med Teach. 2005;27:382-4.

33. Bobryshev Y V, Al-Naggar RA, Al-Musli M, Osman M, Al-Kubaisy W, Daher AM, et al. The Malaysia DREEM: perceptions of medical students about the learning environment in a medical school in Malaysia. Adv Med Educ Pract. 2014;:177. doi:10.2147/AMEP.S61805.

34. Abraham R, Ramnarayan K, Vinod P, Torke S. Students' perceptions of learning environment in an Indian medical school. BMC Med Educ. 2008;8:20. doi:10.1186/1472-6920-8-20.

35. Arzuman H, Yusoff MSB, Chit SP. Big Sib Students' Perceptions of the Educational Environment at the School of Medical Sciences, Universiti Sains Malaysia, using Dundee Ready Educational Environment Measure (DREEM) Inventory. Malays J Med Sci. 2010;17:40-7.

36. Demirören M, Palaoglu O, Kemahli S, Ozyurda F, Ayhan IH. Perceptions of students in different phases of medical education of educational environment: ankara university faculty of medicine. Med Educ Online. 2008;13:8. doi:10.3885/meo.2008.Res00267.

37. Ramani S. Twelve tips for excellent physical examination teaching. Med Teach. 2008;30:851-856.

38. Knowles MS. Gearing adult education for the seventies. J Contin Educ Nurs. 1970;1:11-6.

39. Philbin M, Meier E, Huffman S, Boverie P. A survey of gender and learning styles. Sex Roles. 1995;32:485-94. doi:10.1007/BF01544184.

40. Centra JA, Gaubatz NB. Is There Gender Bias in Student Evaluations of Teaching? J Higher Educ. 2000;71:17-33. doi:10.1080/00221546.2000.11780814. 
41. GILLIGAN, C. \& POLLAK S. The vulnerable and invulnerable physician. In: Mapping the Moral Domain. Harvard University Press; 1988.

42. Khan SQ, Al-Shahrani M, Khabeer A, Farooqi FA, Alshamrani A, Alabduljabbar AM, et al. Medical students' perception of their educational environment at Imam Abdulrahman Bin Faisal University, Kingdom of Saudi Arabia. J Family Community Med. 2019;26:45-50. doi:10.4103/jfcm.JFCM_12_18.

\section{Tables}

Table 1: Background charecteristics of the study population

\begin{tabular}{l|c}
\hline Variable & $\begin{array}{c}\text { N (\%) } \\
\text { Or } \\
\text { Mean (SD) }\end{array}$ \\
\hline Age, years & $19.6(1.5)$ \\
Gender & \\
Male & $361(57.0)$ \\
Female & $273(43.0)$ \\
Academic level & \\
$1^{\text {st }}$ year & $129(20.3)$ \\
$2^{\text {nd }}$ year & $260(41.0)$ \\
$3^{\text {rd }}$ year & $143(22.6)$ \\
$4^{\text {th }}$ year & $80(12.6)$ \\
$5^{\text {th }}$ year & $22(3.2)$ \\
Nationality & \\
Sudanese & $456(71.9)$ \\
Nigerian & $115(18.1)$ \\
South African & $46(7.3)$ \\
Syrian & $9(1.4)$ \\
Egyptian & $8(1.3)$ \\
\hline
\end{tabular}


le 2: DREEM overall score and subclass score among Al-Nahda Medical Students

\begin{tabular}{|c|c|c|c|c|}
\hline Domain & $\begin{array}{c}\text { Number of } \\
\text { items }\end{array}$ & $\begin{array}{l}\text { Maximum } \\
\text { score }\end{array}$ & $\begin{array}{l}\text { Al-Nahda College } \\
\text { findings } \\
\text { Mean (SD) }\end{array}$ & Rating \\
\hline IEM overall & 50 & 200 & $130(34.2)$ & $\begin{array}{l}\text { More positive than } \\
\text { negative }\end{array}$ \\
\hline $\begin{array}{l}\text { lents' perception } \\
\text { earning }\end{array}$ & 12 & 48 & $24(6.0)$ & Negative \\
\hline $\begin{array}{l}\text { lents' perception } \\
\text { :eachers }\end{array}$ & 11 & 44 & $28(8.3)$ & $\begin{array}{l}\text { Moving in the right } \\
\text { direction }\end{array}$ \\
\hline $\begin{array}{l}\text { lents' academic self- } \\
\text { :eption }\end{array}$ & 8 & 32 & $21.5(6.6)$ & More positive \\
\hline $\begin{array}{l}\text { lents' perception of } \\
\text { osphere }\end{array}$ & 12 & 48 & 32.7 (8.3) & $\begin{array}{l}\text { More positive } \\
\text { atmosphere }\end{array}$ \\
\hline $\begin{array}{l}\text { lents' social } \\
\text { perception }\end{array}$ & 7 & 28 & $19.2(5.2)$ & Not too bad \\
\hline
\end{tabular}

e 3: Determinant of students' perception according to DREEM overall and sub-class 


\begin{tabular}{|c|c|c|c|c|c|c|}
\hline tbles & $\begin{array}{l}\text { DREEM } \\
\text { overall } \\
\text { score }\end{array}$ & $\begin{array}{l}\text { Students' } \\
\text { perception } \\
\text { for } \\
\text { learning }\end{array}$ & $\begin{array}{l}\text { Students' } \\
\text { perception } \\
\text { for } \\
\text { teachers }\end{array}$ & $\begin{array}{l}\text { Students' } \\
\text { academic } \\
\text { self- } \\
\text { perception }\end{array}$ & $\begin{array}{l}\text { Students' } \\
\text { perception } \\
\text { of } \\
\text { atmosphere }\end{array}$ & $\begin{array}{l}\text { Students' } \\
\text { social } \\
\text { self- } \\
\text { perception }\end{array}$ \\
\hline \multicolumn{7}{|c|}{ Mean (SD) } \\
\hline \multicolumn{7}{|l|}{ er } \\
\hline & $129(35.5)$ & $23.7(6.1)$ & $27.1(8.5)$ & $21.0(7.2)$ & 32.5 (8.7) & $18.8(5.4)$ \\
\hline le & $136(31.5)$ & $24.5(5.8)$ & $28.8(7.8)$ & $22.2(5.6)$ & 33.07 (7.7) & $19.8(4.9)$ \\
\hline ue & 0.008 & 0.082 & 0.024 & 0.017 & 0.407 & 0.019 \\
\hline \multicolumn{7}{|l|}{ emic } \\
\hline & 132.0 & $24.0(6.0)$ & $27.7(8.1)$ & $21.5(6.5)$ & $32.6(8.1)$ & $19.1(5.2)$ \\
\hline & (33.3) & $24.3(6.1)$ & $28.2(9.0)$ & $21.5(7.3)$ & $33.0(9.3)$ & $19.5(5.3)$ \\
\hline al & 132.8 & & & & & \\
\hline al & (38.3) & 0.780 & 0.821 & 0.922 & 0.954 & 0.658 \\
\hline
\end{tabular}

ue $\quad 0.946$

le 4: DREEM overall score and subclass score among Al-Nahda Medical Students detailed ıcademic levels 


\begin{tabular}{|c|c|c|c|c|c|c|}
\hline & $\begin{array}{l}1^{\text {st }} \text { year } \\
n=129\end{array}$ & $\begin{array}{l}2^{\text {nd }} \text { year } \\
n=260\end{array}$ & $\begin{array}{l}3^{\text {rd }} \text { year } \\
n=143\end{array}$ & $\begin{array}{c}4^{\text {th }} \text { year } \\
n=80\end{array}$ & $\begin{array}{l}5^{\text {th }} \text { year } \\
n=22\end{array}$ & $\begin{array}{l}\text { P-value* } \\
\text { Between } \\
\text { groups }\end{array}$ \\
\hline & \multicolumn{5}{|c|}{ Mean (SD) } & \\
\hline $\begin{array}{l}y^{\prime} \\
\text { on } \\
\text { ing }\end{array}$ & $23.7(6.4)$ & $24.2(5.6)$ & $24.1(6.2)$ & $24.1(6.2)$ & $24.8(6.0)$ & 0.910 \\
\hline $\begin{array}{l}\text { on } \\
\text { iers }\end{array}$ & $27.5(9.3)$ & $28.1(6.8)$ & $28.2(9.3)$ & $28.1(6.3)$ & $28.6(9.0)$ & 0.959 \\
\hline $\begin{array}{l}\text { c } \\
\text { on }\end{array}$ & $20.7(7.6)$ & $22.2(5.3)$ & $21.3(7.5)$ & $21.4(6.2)$ & $20.9(7.3)$ & 0.394 \\
\hline $\begin{array}{l}\text { on of } \\
\text { ere }\end{array}$ & $32.5(9.4)$ & $33.0(6.5)$ & $33.1(9.6)$ & $32.8(9.3)$ & $33.5(9.7)$ & 0.973 \\
\hline on & $18.8(5.7)$ & $19.3(4.8)$ & $19.4(5.4)$ & $19.1(4.4)$ & $20.0(5.22)$ & 0.822 \\
\hline & $\begin{array}{l}128.5 \\
(39.5)\end{array}$ & $135.9(26.0)$ & 132.1(38.6) & $132.0(38.3)$ & 135.6(39.1) & 0.399 \\
\hline
\end{tabular}

*ANOVA followed by Tukey's test.

i: Detailed item scores for educational environment of medical school in Al-Nahda College 


\section{dents' perception of Learning}

a encouraged to participate during teaching sessions.

$2.08(1.59)$

teaching is often stimulating

$3.20(0.663)$

teaching is students centered

$3.05(1.169)$

teaching helps to develop my competence

$2.97(1.138)$

teaching is well focused

$2.56(1.170)$

teaching time is put to good use

$2.59(1.104)$

teaching over emphasizes factual learning

$2.89(1.086)$

teaching helps to develop my confidence

$2.65(1.041)$

a clear about the learning objectives of the course

$2.19(1.363)$

teaching encourages me to be an active learner

$2.59(1.180)$

ı term learning is emphasized over short term learning

$2.37(1.166)$

teaching is too teacher centered

$2.59(0.981)$

\section{dents' perception of teachers}

course teachers are knowledgeable.

teachers are patient with patients/ students' consultations 
dents' academic self-perception

rning strategies which worked for me before, continue to work $2.95(1.120)$ me now.

a confident about my passing this year

el I am being well prepared for my profession

t years work has been a good preparation for this years work

$2.71(1.369)$

a able to memorize all I need

ve learnt a lot about empathy in my profession

problem-solving skills are being well developed here

sh of what I have to learn seems relevant to a career in $2.65(1.031)$ lthcare dents' perception of atmosphere

school is well timetabled 
re are opportunities for me to develop interpersonal skills

əl comfortable in teaching sessions socially

atmosphere is relaxed during seminars / tutorials

ıd the experience disappointing

a able to concentrate well

enjoyment outweighs the stress of the course

atmosphere motivates me as a learner

əl able to ask the questions I want
$2.92(1.160)$

$2.72(1.084)$

$2.85(0.989)$

$3.11(1.056)$

$2.44(1.261)$

$2.65(1.220)$

$2.35(1.149)$

$2.79(0.937)$

dents' social-self-perception

re is a good support system for students who get stressed.

$2.57(1.183)$

a too tired to enjoy the course.

$2.53(1.259)$

a rarely bored on this semester

$2.89(1.108)$

ve good friends on this school

$3.04(1.065)$

social life is good

$2.60(0.898)$

ldom feel lonely

$2.92(1.164)$

accommodation is pleasant

$2.72(0.959)$ 
i: Linear regression analysis model to predict affector of overall DREEM score

\begin{tabular}{|l|c|c|c|l|}
\hline Je & $\beta$ & SE & $P$-value & 95\% CI \\
\hline its' Gender & 7.65 & 2.91 & 0.009 & $1.94-13.37$ \\
\hline mic level & 0.65 & 1.33 & 0.622 & $-1.96-3.28$ \\
\hline Ialities & 2.91 & 1.79 & 0.105 & $-0.61-6.43$ \\
\hline
\end{tabular}

Figures 


\section{Respondent Distribution by Nationality}

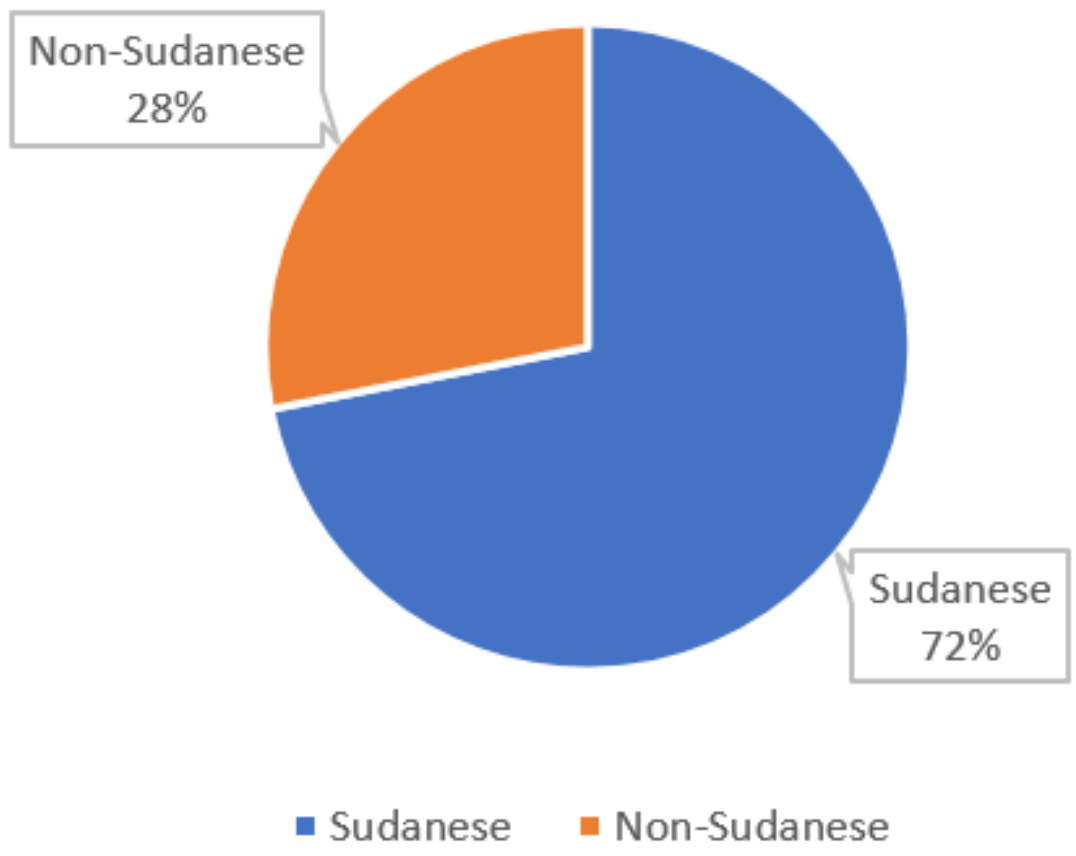

Figure 1

Respondent Distribution by Nationality Pie-chart showed the distribution of respondent according to their nationalities.

\section{Supplementary Files}

This is a list of supplementary files associated with this preprint. Click to download.

- STROBEchecklist.doc 